\title{
MENINGITIS IN THE NEWBORN
}

BY

\author{
W. S. CRAIG, B.Sc., M.D., M.R.C.P.E.
}

Hon. Assistant Paediatrician, Royal Maternity and Simpson Memorial Hospital; Assistant Physician, Western General Hospital; and Lecturer, University Department of Child Life and Health, Edinburgh.

Infection constitutes the most serious threat to survival with which the newborn infant has to contend. It may involve superficial or deep structures and frequently gives rise to septicaemia: In the present paper an account is given of the clinical and pathological features of twenty-one cases of neonatal meningitis (with special reference to the importance of morbid conditions of the skin and surface mucous membranes as primary foci of infection) occurring in the Royal Maternity Hospital, Edinburgh, during the past four years. Observations were made and recorded in connection with twenty of these infants from the time of birth in the course of routine clinical duties. One child, born at home, first came under observation after admission to hospital on the third day of life. Post-mortem examination was carried out in eighteen cases; in the other three cases permission for autopsy was not obtained and diagnosis was based upon the results of examination of cerebrospinal fluids obtained during life.

\section{Clinical and pathological records.}

Obstetrical details. - Of the twenty-one cases included in the series six were born at term, seven were four weeks and eight more than six weeks premature. Delivery was instrumental in one case and spontaneous in the remaining twenty which included four breech presentations. Meconium was passed in the course of four labours. There was a history of antenatal toxaemia in the case of four, and of a morbid puerperium in two mothers.

Clinical observations. - The dominating characteristics of the clinical picture were lack of desire for fluids, increasing bodily weakness and a stationary or falling weight. Other features were pronounced in only a limited number of infants. The picture was complicated by the presence of pneumonia in six and severe gastro-intestinal disturbance in two cases; atelectasis was present in a large number. A tentative diagnosis of meningitis was made during life in thirteen cases, in three of which the condition was thought to be intracranial haemorrhage prior to the examination of spinal fluid. The presence of an intracranial abnormality was not suspected in seven cases.

The condition of seventeen of the twenty-one infants was unsatisfactory at birth; four were severely asphyxiated and the remainder very feeble. 
These infants never rallied satisfactorily. Their weight failed to increase after the initial physiological loss; in the smallest infants it remained stationary throughout life, in others it showed a persistent gradual decline (fig. 1, 2 and 3). Slow progressive wasting was characteristic. Typical

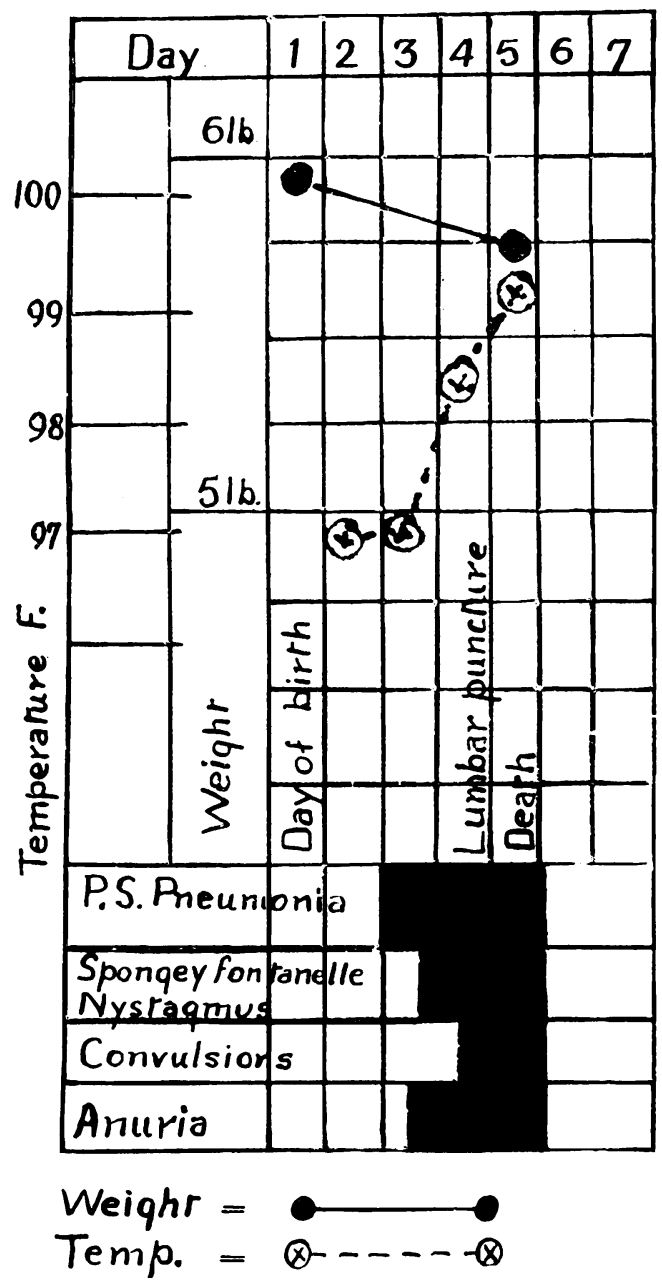

Fig. 1.-Baby C.; three weeks premature, spontaneous delivery; asphyxiated at birth. Physical signs of pneumonia present on the third day of life. Diagnosis of meningitis confirmed by lumbar puncture on the fourth day and death on the fifth day of life. Pneumonia, pulmonary abscesses and extensive meningitis (b. coli) present at autopsy.

Hippocratic facies developed in some cases. In a few an expression of great anxiety was associated with continual restless movements of the head; in two there was repeated, darting protrusion of the tongue; the picture was one of great mental restlessness associated with extreme physical weakness. Ocular signs were among the early evidences of intracranial irritation; they included inequality of the pupils, gross muscular inco-ordination in a few, and, more commonly, fine lateral nystagmus. Tendon reflexes showed no constant changes; they were exaggerated in the presence of signs of cerebral irritation but diminished in the majority of instances. General convulsions occurred in two infants in whom Babinski's sign and nuchal rigidity had been 


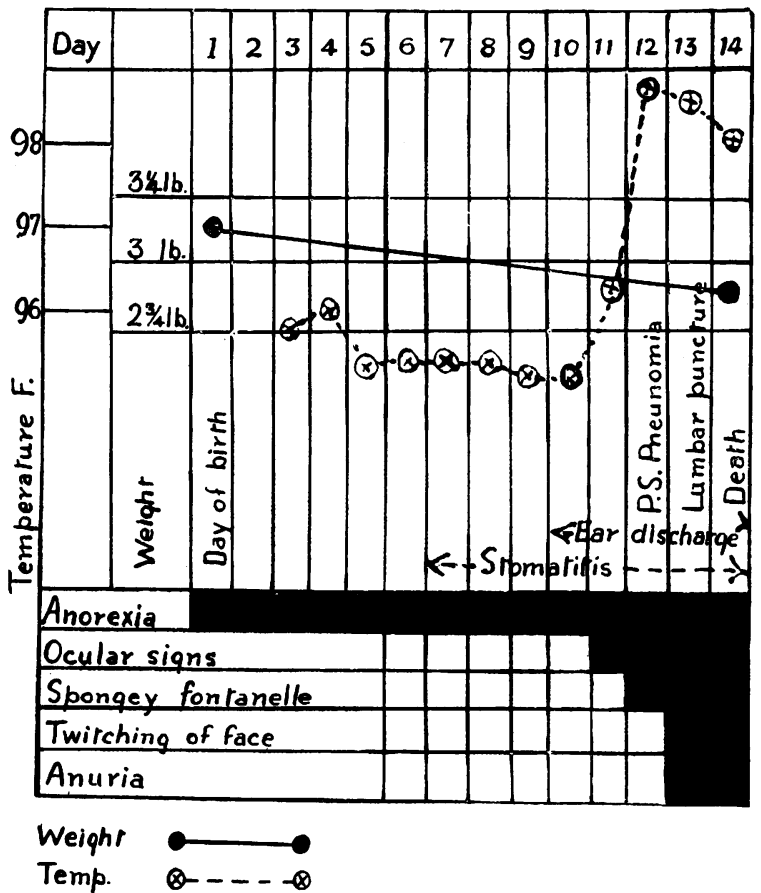

Frg. 2-Baby R.; four weeks premature; spontaneous delivery; condition poor at birth; b. coli cultured during life from aural discharge and mouth; lumbar puncture on thirteenth day of life confirmed diagnosis of meningitis. Death on fourteenth day. At autopsy extensive meningitis (b. coli), bilateral otitis media, stomatitis, pneumonia.

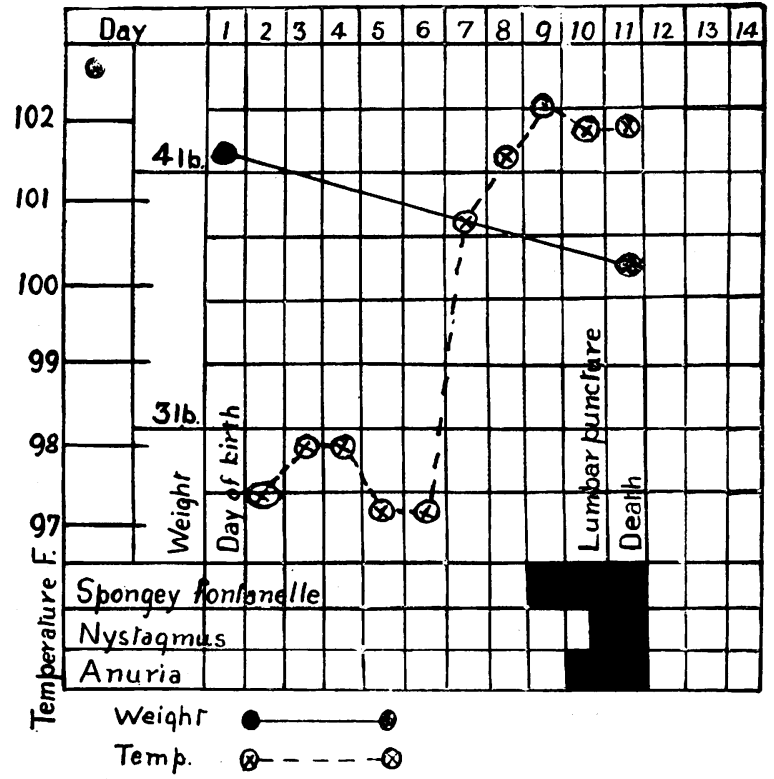

Fig. 3.-Baby S.; seven weeks premature; spontaneous delivery; poor condition at birth; lumbar puncture after appearance of ocular signs on tenth day of life confirmed diagnosis of meningitis. Extensive meningitis at autopsy (b. coli). 
previously observed; they were preceded by a shrill cry, were followed by a period of coma and recurred immediately before death. Localized twitching of the extremities or face, or both, occurred in eight infants; unilateral facial palsy subsequently developed in two, a right ptosis in one and slight spasticity of the limbs in four. In nine cases a spongey sensation was appreciated on palpation of the fontanelle; this was due to fullness rather than to increased tension. Vomiting was recorded in only one infant and was not projectile. Curious movements involving the upper limbs were a feature of two cases; in one they consisted of a persistent fine tremor of the hands and in the other were suggestive of ataxia. The pulse tended to increase in rate but became imperceptible and made observations in connection with it unreliable. Three infants showed no fever (fig. 4). In the other

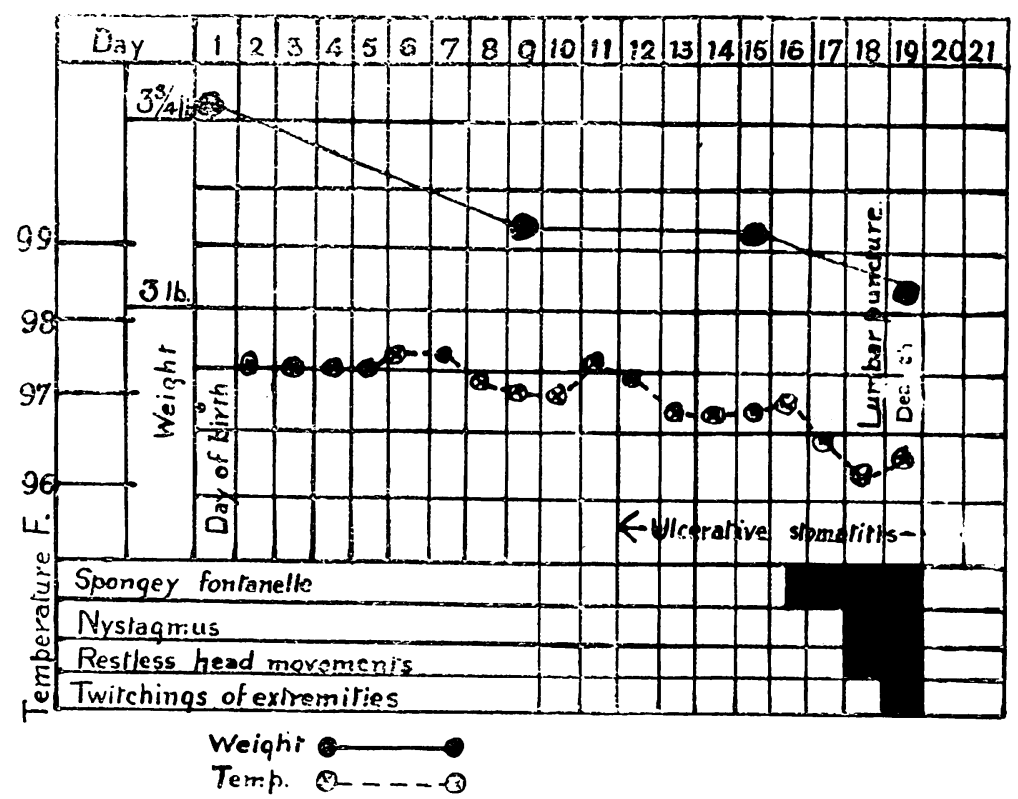

FIG. 4.-Baby L.; six weeks premature; poor condition at birth; lumbar puncture after appearance of ocular signs and evidence of mental restlessness confirmed diagnosis of meningitis. Note unusual afebrile course. Meningitis very extensive at autopsy; streptococcus cultured from c.s.f. taken during life and from smear from meninges taken at autopsy.

cases the temperature was subnormal for some time after birth but ruse with remarkable constancy two to four days before death, reaching a maximum exceeding $102^{\circ} \mathrm{F}$. in only cne instance: it fell slightly during the last few hours of life. In two cases death was preceded by convulsions and in the others followed a short period of semi-coma. Failure to excrete urine was a feature of the terminal stages. The duration of life varied from four to twenty days; seven infants died in each of the first three weeks of life. Lumbar puncture was carried out during life in eight infants. The results of the examination of the fluids are given in table 1 , 


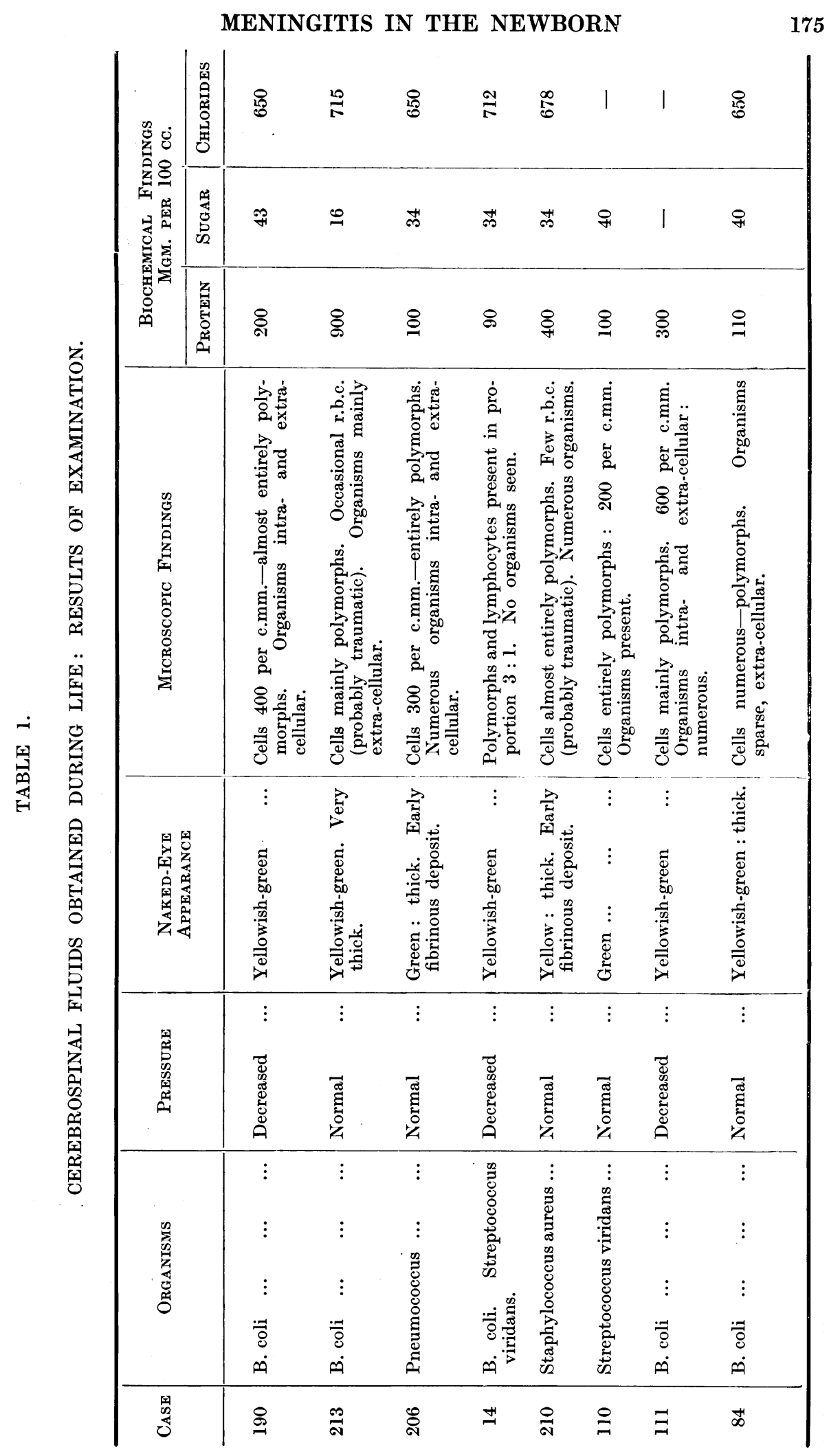

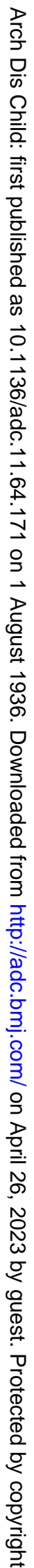




\begin{tabular}{|c|c|c|c|c|}
\hline \multirow[b]{2}{*}{ Case } & \multicolumn{3}{|c|}{ CLINICAL FINDINGS. } & PATHOLOGICAL \\
\hline & Meningitis & $\begin{array}{l}\text { DURATION } \\
\text { OF LIFE } \\
\text { (DAYS) }\end{array}$ & $\begin{array}{l}\text { Associated } \\
\text { Morbid } \\
\text { Conditions }\end{array}$ & Meningeat Exudate \\
\hline 209 & $\begin{array}{l}\text { Tentative diagnosis made } 48 \\
\text { hours before death. }\end{array}$ & 10 & $\begin{array}{l}\text { Purulent conjunctivitis } \\
\text { with corneal ulceration. }\end{array}$ & $\begin{array}{l}\text { Thick : patchy, yellow : mainly } \\
\text { basal but also over vertex. }\end{array}$ \\
\hline 210 & Diagnosed $\quad \ldots \quad \ldots \quad \ldots$ & 15 & $\begin{array}{l}\text { Dorsal meningo-myelo- } \\
\text { coele. }\end{array}$ & $\begin{array}{l}\text { Thick : yellow: base of brain } \\
\text { and spinal meninges. }\end{array}$ \\
\hline 241 & $\begin{array}{l}\text { Tentative diagnosis made } 48 \\
\text { hours before death. }\end{array}$ & 14 & $\begin{array}{l}\text { Ulcerative stomatitis. } \\
\text { Purulent nasal discharge. } \\
\text { Cellulitis of scalp. }\end{array}$ & $\begin{array}{l}\text { Massive : greenish yellow : } \\
\text { covering entire brain. }\end{array}$ \\
\hline 214 & $\begin{array}{l}\text { Tentative diagnosis made on } \\
\text { day of death. }\end{array}$ & 7 & $\begin{array}{l}\text { Dermatitis. Aural dis- } \\
\text { charge. }\end{array}$ & $\begin{array}{l}\text { Patchy : greenish yellow : main- } \\
\text { ly basal but also over vertex. }\end{array}$ \\
\hline 212 & Not suspected & 11 & Subcutaneous abscess ... & $\begin{array}{l}\text { Thick: bright yellow: mainly } \\
\text { basal but also related to } \\
\text { parietal surface. }\end{array}$ \\
\hline 211 & Not suspected & 20 & Pneumonia $\quad \ldots$ & $\begin{array}{l}\text { Thick ; green : limited to under } \\
\text { surfaces of temporal and frontal } \\
\text { lobes. }\end{array}$ \\
\hline 110 & $\begin{array}{l}\text { Tentative diagnosis of intra- } \\
\text { ventricular haemorrhage, re- } \\
\text { vised following lumbar punc- } \\
\text { ture. }\end{array}$ & 6 & Pneumonia $\quad \ldots$ & $\begin{array}{l}\text { Massive : related to all external } \\
\text { cerebral surfaces. }\end{array}$ \\
\hline 190 & $\begin{array}{l}\text { Diagnosis confirmed by lum- } \\
\text { bar puncture. }\end{array}$ & 11 & $\begin{array}{l}\text { Pneumonia } \\
\text { ? Peritonitis. }\end{array}$ & $\begin{array}{l}\text { Massive : greenish yellow: re- } \\
\text { lated to all external cerebral } \\
\text { surfaces. }\end{array}$ \\
\hline 213 & $\begin{array}{l}\text { Diagnosis confirmed by lum- } \\
\text { bar puncture. }\end{array}$ & 4 & Pneumonia $\quad \ldots$ & $\begin{array}{l}\text { Thick : green : localized to } \\
\text { base of brain. }\end{array}$ \\
\hline 235 & $\begin{array}{l}\text { Intracranial condition suspec- } \\
\text { ted. }\end{array}$ & 17 & - & $\begin{array}{l}\text { Thick: greenish yellow : limited } \\
\text { to lateral fissures and under } \\
\text { surface of temporal lobe. }\end{array}$ \\
\hline 125 & Not suspected $\quad \ldots \quad \ldots$ & 16 & Pneumonia $\quad \ldots \quad \ldots$ & $\begin{array}{l}\text { Massive : yellow : mainly basal } \\
\text { and involving all surfaces of } \\
\text { pons and cerebellum. }\end{array}$ \\
\hline 143 & $\begin{array}{l}\text { Tentative diagnosis made } 36 \\
\text { hours before death. }\end{array}$ & 11 & Ulcerative stomatitis ... & $\begin{array}{l}\text { Massive : greenish yellow : main- } \\
\text { ly basal involving pons and } \\
\text { cerebellum. }\end{array}$ \\
\hline 205 & Not suspected & 15 & Aural discharge (bilateral) & $\begin{array}{l}\text { Sparse-in thin, small patches, } \\
\text { limited to under surface of } \\
\text { occipital lobe: green. }\end{array}$ \\
\hline 206 & $\begin{array}{l}\text { Diagnosis confirmed by lum- } \\
\text { bar puncture. }\end{array}$ & 4 & Purulent nasal discharge & $\begin{array}{l}\text { Patchy, but extensive and thick: } \\
\text { related to all external surfaces } \\
\text { of cerebrum : green. }\end{array}$ \\
\hline 207 & Not suspected & 12 & $\begin{array}{l}\text { Ulcerative stomatitis. } \\
\text { Acute intestinal distur- } \\
\text { bance. }\end{array}$ & $\begin{array}{l}\text { Moderately thick: greenish yel- } \\
\text { low: limited to under surface } \\
\text { right temporal lobe. }\end{array}$ \\
\hline 208 & Not suspected & 7 & $\begin{array}{l}\text { Extensive pustular skin } \\
\text { condition. Pneumonia. }\end{array}$ & $\begin{array}{l}\text { Thin : greenish yellow : limited } \\
\text { to lateral surface of left parietal } \\
\text { lobe. }\end{array}$ \\
\hline 243 & Not suspected & 8 & $\begin{array}{l}\text { Pneumonia. Purulent } \\
\text { nasal discharge. }\end{array}$ & $\begin{array}{l}\text { Sparse : greenish yellow : limit- } \\
\text { ed to the under surface of the } \\
\text { occipital lobe. }\end{array}$ \\
\hline 251 & $\begin{array}{l}\text { Intraventricular haemorrhage } \\
\text { suspected : diagnosis re- } \\
\text { vised following lumbar punc- } \\
\text { ture. }\end{array}$ & 19 & - & Thick: green : mainly basal. \\
\hline 111 & $\begin{array}{l}\text { Intraventricular haemorrhage } \\
\text { suspected : diagnosis re- } \\
\text { vised following lumbar punc- } \\
\text { ture. }\end{array}$ & 14 & Cellulitis of scalp & No autopsy \\
\hline 84 & $\begin{array}{l}\text { Diagnosis confirmed by lum- } \\
\text { bar puncture. }\end{array}$ & 6 & $\begin{array}{l}\text { Acute alimentary distur- } \\
\text { bance. Infection of } \\
\text { cephalohaematoma. }\end{array}$ & No autopsy \\
\hline 14 & $\begin{array}{l}\text { Diagnosis confirmed by lum- } \\
\text { bar puncture. }\end{array}$ & 20 & & No autopsy \\
\hline
\end{tabular}

* From material obtained during life. 
LE 2.

21 CASES OF NEONATAL MENINGITIS.

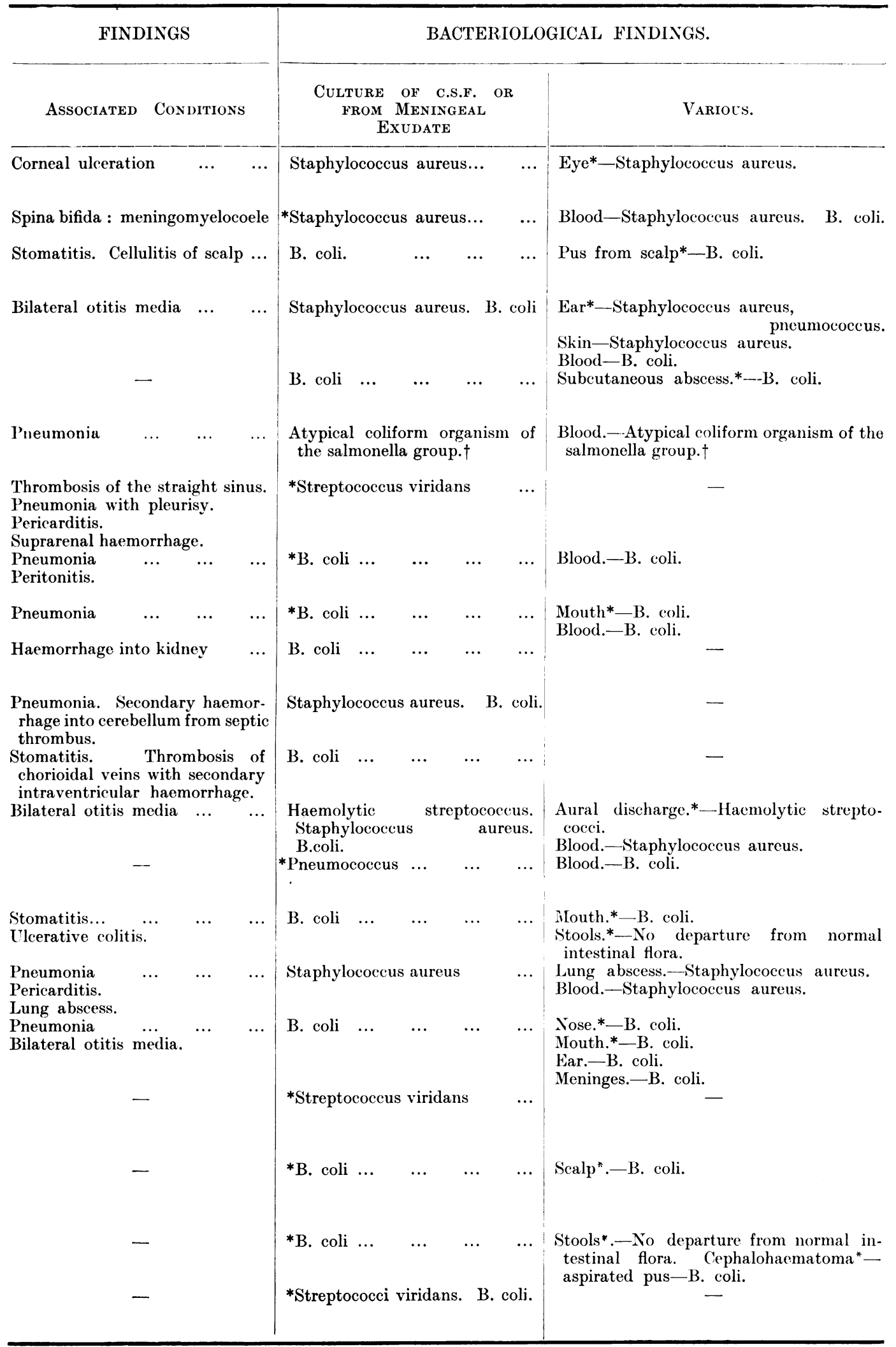


Infection of the skin, mucous membranes or subcutaneous tissues was a common finding. In one infant pustules developed over the entire body on the second day of life and disappeared several days before death: in another the appearance of extensive dermatitis preceded death by five days. Ulcerative stomatitis was a feature of four cases : in one there was purulent conjunctivitis with ulceration of the cornea and purulent discharge was noted from the nose in three, and from the ears in two cases. Localized cellulitis of the scalp arose from infection of a superficial forcep's abrasion in one case and of a laceration resulting from the application of Willet's forceps in another: in a third there was secondary infection of a cephalohaematoma. Meningitis followed the development of sepsis in a large dorsal meningomyelocoele in one child. Examination of the urine in sixteen cases showed nothing abnormal.

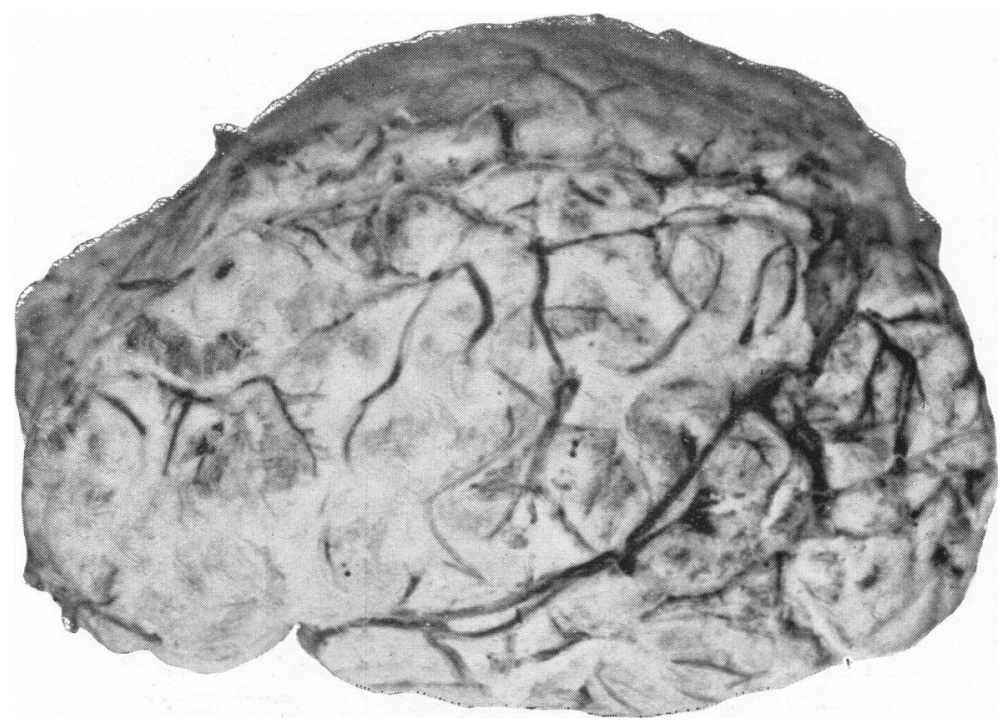

FIG. 5.-Baby S.; b. coli meningitis in infant dying on eleventh day of life, showing thick inflammatory deposit extending over the whole of the lateral surfaces of the cerebrum. Signs suggestive of meningitis did not appear until two days before death.

Pathological findings. - The extent of the inflammatory exudate varied. In some cases there was a thin deposit along the lines of the meningeal vessels; in others a thick exudate was limited to the base of the brain and the lateral fissures; in a few a massive purulent deposit extended uniformly from the vertex to base (fig. 5) and involved the surfaces of mid-brain and cerebellum. Intense generalized congestion of the meninges was characteristic even in cases where the inflammatory deposit was strictly localized. The choroid plexus was covered in a number of cases, and the ventricular walls in a few instances with exudate similar in nature to that on the surface of the brain. Abundant exudate was sometimes accompanied by flattening of the cerebral convolutions over the vertex. In two of the three cases in which the cord was examined there was involvement of the spinal meninges. 
Microscopically the meningeal exudate presented the usual features (fig. 6). Organisms were present in large numbers and in advanced cases phagocytosis of polymorphonuclear cells by macrophages was evident. The amount of fibrin present varied. Apart from the occurrence of intracerebellar haemorrhage in one case (see below) changes in the brain substance were limited to slight congestion and oedema.

Associated conditions found at autopsy included pneumonia in seven, pericarditis in two, ulcerative colitis in one, peritonitis in one and otitis media in three infants. Pneumonia had developed around pulmonary

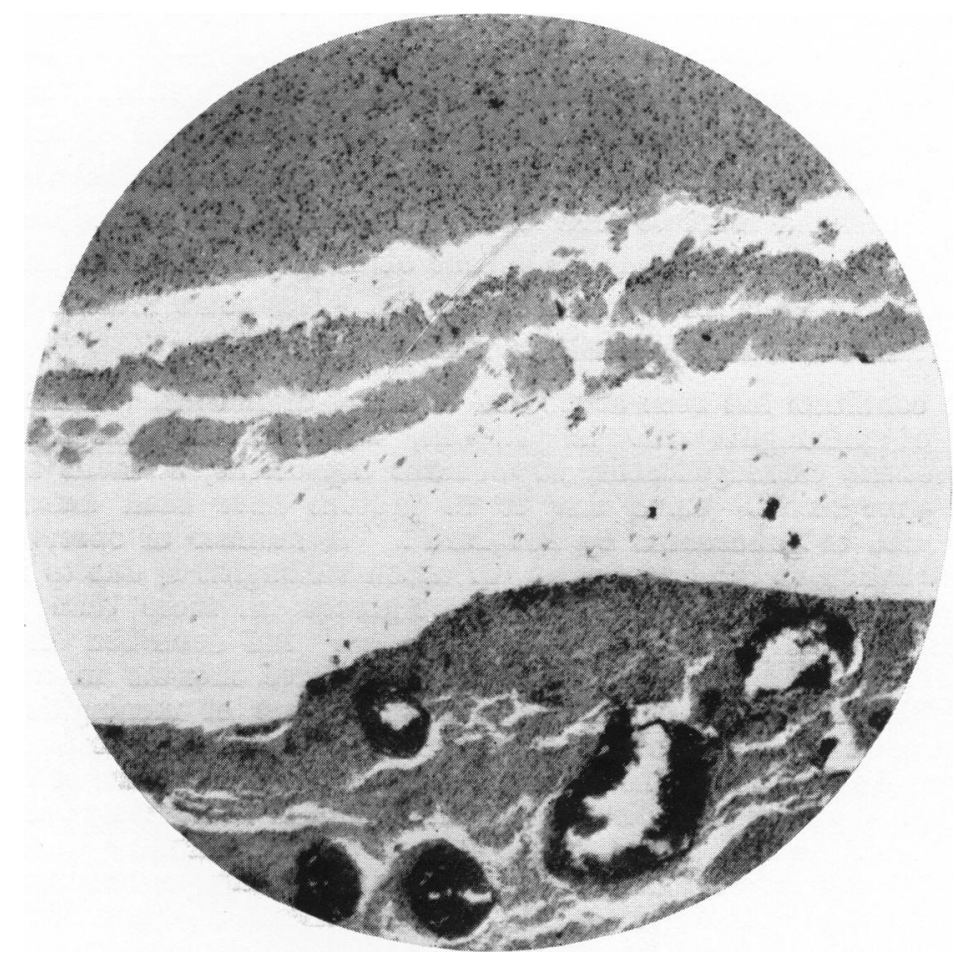

FIg. 6.-Baby L. Thick exudate (cells and fibrin) in a case of pneumocococcal meningitis dying on the fourth day of life. There is severe congestion of the brain substance. Symptoms suggestive of an intra-cranial condition did not appear until within eighteen hours of death.

abscesses in one case and was associated with empyema in another. Atelectasis of varying extent was present in the majority of cases.

Haemorrhage arising from thrombosed vessels was present in three cases. In one the cerebral ventricular system was filled with blood arising from the veins of the chorioid plexus; in another extensive subdural haemorrhage had followed thrombosis of the straight sinus; and in the third case localized haemorrhage had taken place into the medullary substance of the cerebellum. 
Bacteriological findings.- These are given in table 2. A pure culture of b. coli was grown from the meninges or spinal fluid in ten cases: in three mixed growths included b. coli. In one case meningitis was due to infection by an atypical organism of the Salmonella group and in the remainder to infection by the common pyogenic organisms.

\section{Discussion.}

Eighteen of the twenty-one cases of the present series came to autopsy; they represent almost 8 per cent. of the two hundred and thirty post-mortem examinations carried out on newborn infants by the writer during the period of this study. Cruickshank ${ }^{11}$ found meningitis in 4 per cent. of eight hundred cases of neonatal death. His thirty-three cases of meningitis included fourteen premature infants ( 42 per cent.): in the present series there were fifteen premature infants or 71 per cent. of the total of twenty-one cases. The differences 'between the two series indicate the care with which general conclusions must be arrived at in the study of a limited number of cases. A review of the more important observations made in connection with neonatal meningitis by various workers gives some indication of the many factors which may give rise to these differences.

The condition has been attributed to many organisms. Barron ${ }^{4}$ found records of meningitis due to b. coli, streptococcus, staphylococcus, pneumococcus, meningococcus, b. mucosus capsulatus, b. lactis aerogenes and $b$. pyocyaneus. Cases due to b. proteus have been described by Cathala $^{7}$ and to gonococcus by Bradford ${ }^{5}$. A number of observers have drawn attention to the frequency with which meningitis is due to infection by b. coli. Cruickshank ${ }^{11}$ found this organism in more than half the autopsies on twenty-three infants and Gibbens ${ }^{13}$ has described three cases which came to autopsy' within a period of twelve months in a London hospital. Scherer ${ }^{23}$ was of the opinion that cases of meningitis due to b. coli in newborn infants occurred with greater frequency in hospital during periods of overcrowding. In explanation of the high incidence of this form of meningitis Cooke and $\mathrm{Bell}^{8}$ argue that there is decreased resistance to bacterial infection as the result of the absence of ' the normal agglutinins for b. coli' in the newborn; they also refer to the greater permeability of the intestinal mucosa at that age and stress the influence of digestive disturbance.

The pathological findings recorded by a number of writers indicate that meningitis is frequently the result of generalized septicaemia and Fothergill and Sweet ${ }^{12}$ isolated b. coli during life from the blood and spinal fluid of several cases of meningitis in the newborn.

The time at which infection occurs varies and may be related to antenatal, natal or postnatal factors. Athenstaedt ${ }^{2}$ describes a case of $b$. coli septicaemia involving the meninges in a newborn infant in which he considers transplacental transmission of infection from a maternal pyelitis took place. Hinsdale $^{16}$ records a case in which neonatal meningitis followed umbilical infection derived from an intrauterine collection of pus. Infection is attributed to the introduction of a finger into the infant's mouth during labour in a case described by Barron ${ }^{4}$. Goldreich ${ }^{14}$ reports a fourth case in which meningitis was present at autopsy on the second day of life, having given rise to symptoms during the previous twenty-four hours; he considers that infection was antenatal, was favoured by a long dry labour and was was aspirated into the lungs. 
Infection has been attributed to aspiration of infected liquor amnii by Aschoff $^{3}$ and Herrman ${ }^{15}$ among others. This mode of infection has been emphasized by Browne ${ }^{6}$ in connection with neonatal pneumonia. Pulmonary infection may result in septicaemia and subsequent meningitis but, as Cruickshank $^{11}$ remarks, difficulty exists in determining whether the pneumonia is a primary or a secondary factor. The alimentary and urinary tracts are suggested as possible portals of entry for infection by Gibbens ${ }^{13}$ and Herrman ${ }^{15}$.

There are several references in the literature to the association of otitis media with meningitis in the newborn. It is probable that in these cases infection of the meninges was a result of direct spread from the ear. In two cases recorded by Cruickshank ${ }^{11}$ b. coli was cultured from both the meninges and the ears. The occurrence of otitis media in the newborn is attributed by Aschoff ${ }^{3}$ to the passage of infected liquor amnii along the eustachian tubes as a result of efforts at premature respiration. Scherer ${ }^{23}$ suggests that otitis media may follow the lodgment of infected bath water in the ear.

Observers agree regarding the difficulty in diagnosing meningitis in newborn infants. The condition was not suspected during life in a large number of the recorded cases. Gibbens ${ }^{13}$ explains the frequent absence of evidence of increased intracranial pressure by the ability of the skull of the newborn infant to adapt itself within certain limits to increase in the volume of its contents. The same author agrees also with the view expressed by Koplik $^{17}$ that meningitis may be confused with tetany. Ravid ${ }^{20}$ points out that meningitis may be indicated by the least specific signs; in this connection he considers that the condition is nearly always ushered in by gastro-intestinal disturbance and attaches importance to distension of the veins of the neck and to dissociation of the pulse rate and temperature. He describes fever as irregular in these cases: von Reuss ${ }^{21}$ is of the opinion that it may be entirely absent or very insignificant, and stresses a tense, bulging fontanelle and convulsions as among the most helpful points in diagnosis: he considers the late appearance of convulsions of value in differentiating the condition from birth trauma. An unusual case of recovery from $b$. coli meningitis is recorded by $\mathrm{Neff}^{19}$, but it is significant that the question of treatment receives no attention in the literature.

Present series.-In the present series it was not always possible to determine whether extension of the infection to the meninges had been direct or by the blood stream, but the pathological and bacteriological findings leave little doubt that primary foci of infection were present in the skin (two cases), the tissues of the scalp (two cases), and the eyes (one case). Pathological evidence of septicaemia was present in ten cases, in six of which confirmation was obtained as a result of bacteriological examination of autopsy material. The presence of ulcerative colitis suggests that infection of the blood may have occurred in the intestine in one case. Considering the frequency with which primary foci are demonstrable in other situations alimentary infection must necessarily be rare, and little significance can be attached to gastro-intestinal symptoms as evidence of the mode of infection. Infection of the blood may have occurred in the lungs of the seven infants in which pneumonia was present. In four of these cases superficial septic foci appeared a considerable time before signs and symptoms suggestive of pneumonia, and it is probable that in these cases pulmonary lesions were secondary manifestations of a generalized septicaemia. 
There was no evidence of urinary infection in any of the cases under discussion. In a series of sixty-one cases of urinary infection in the newborn the present writer $^{10}$ found no evidence of meningitis: the great majority of such cases recover. It may be assumed from these facts that meningitis rarely results from a primary infection of the urinary tract.

In three cases meningitis was the result of direct extension of infection from the ear. In two of these cases infection was present in the bucco-nasal cavities and the otitis media is probably explained by the passage of organisms along the eustachian tube. The third case may be explained in the same way despite the absence of any obvious focus of infection as Aries $^{1}$ has drawn attention to the frequent presence of organisms in the mouths of apparently healthy newborn infants. The view expressed by Leathart ${ }^{18}$ would suggst that the supine position in which these debilitated infants were fed was a factor favouring extension of infection in the way described. These facts show that in discussing neonatal meningitis the same importance is to be attached to infections of the upper respiratory passages as of the skin, eye and scalp as potential primary foci of infection.

Meningitis of the newborn due to an organism of the Salmonella group has not been previously recorded. In other respects the bacteriological findings in the present series do not differ from those mentioned by earlier writers. A feature of the cases under discussion was the frequency with which the b. coli was responsible for infection of the superficial tissues. This observation suggests that the large number of cases of neonatal meningitis due to $b$. coli is largely accounted for by the many risks of exposure to infection by that organism peculiar to newborn infants.

The appearance of the meningeal exudate gave no clue as to the nature of the casual organism but its distribution explained certain clinical features. The absence of classical signs of meningitis was accounted for in several infants by the sparse nature of the inflammatory exudate. In other infants the clinical signs were those of cranial nerve involvement and were explained by the localization of the meningeal deposit over the base of the brain. This was a feature of a number of autopsies and explained the infrequency with which cortical irritation gave rise to convulsive movements.

The explanation given by Gibbens ${ }^{13}$ for the absence of signs arising from increased intracranial pressure finds support in two observations made in connection with the present series. In the first place there were symptoms of increased intracranial pressure in only two cases : they appeared abruptly, were rapidly followed by death and at autopsy were explained by gross intracranial haemorrhage complicating meningitis. In these cases it may be assumed that the skull was unable to adapt itself to the sudden massive increase in the bulk of its contents resulting from haemorrhage. In the second place, the findings reported here confirm the views held by von Reuss ${ }^{21}$ that meningitis is particularly liable to occur in premature infants. The loose nature of the membranes connecting the bones of the skull in these infants would appear to indicate that the theory advanced by Gibbens has a special application in their case. It is possible therefore that the predominance of 
premature infants in cases of neonatal meningitis seen in the present series accounts for the infrequency with which symptoms of increased intracranial pressure appear.

The frequent absence of classical signs makes the diagnosis of meningitis in the newborn difficult. It is important to remember the possibility of the condition and to note the existence of predisposing factors. Chief among these are prematurity and the presence of infection. Both of these factors were present in fifteen of the cases under discussion. Meningitis is particularly liable to occur where sepsis develops in a premature infant whose clinical course since birth has been characterized by a falling or stationary weight curve and by slowly increasing physical weakness. Neonatal pneumonia has to be considered in the differential diagnosis and difficulty may arise from the combined presence of pneumonia and meningitis as seen in six cases of this series. As already described by the present writer ${ }^{9}$ the existence of pneumonia is suggested by attacks of slight cyanosis which disappear with the administration of oxygen and can usually be confirmed by auscultatory findings.

Signs of intracranial disturbance occurring after the first week of life should always suggest meningitis. They were characteristic of over 66 per cent. of our cases. The clinical signs which proved of greatest value in the present series were ocular inco-ordination and nystagmus, especially when associated with an expression of fear or with restless movements of the head. Importance was always attached to ' sponginess' of the fontanelle. Intraventricular haemorrhage is frequently associated with the late appearance of similar features but they are more abrupt in onset, severer in nature and accompanied by signs of more acute general distress: the fontanelle bulges and is tense, the cry is shriller and convulsive movements of the limbs are grosser than in cases of meningitis. In both conditions death is usually preceded by a rise in temperature but whereas in cases of meningitis it is present for two to four days (fig. 1 and 3), it is a strictly terminal event in intraventricular haemorrhage.

Lumbar puncture is essential for a final diagnosis. The presence of meningitis is suggested by the colour and the turbidity of the fluid obtained and can be rapidly confirmed by microscopical examination. The results of biochemical examination of the few specimens of spinal fluid obtained, did not differ from those recorded in similar cases occurring in older children.

The case of partial recovery described by $\mathrm{Neff}^{19}$ must be considered a rare exception. Treatment of the developed condition is limited to the amelioration of symptoms and preventive measures are the only ones which can influence the neonatal death rate due to meningitis. Prevention depends upon the elimination of the risks of infection to which infants are exposed in the neonatal period.

In any study of meningitis the source and the mode of infection are points of primary importance. Many views have been advanced in this connection in discussions dealing with the condition in the newborn. Observations made on cases included in the present series reveal the 
importance of morbid conditions of the skin and surface mucous membranes as primary foci of infection. In the majority of cases infection of these structures was not evident for a considerable time after birth and was probably derived from the mother, the attendants or, in the case of infants not on the breast, from the feeds. Surface infections appearing during the first few days of life may have been derived from similar sources or acquired during labour from infected liquor amnii or the external genitalia.

The risks attached to morbid conditions of the skin and mucous membranes in the newborn is not sufficiently appreciated. Prevention depends upon meticulous attention to the hygiene of the skin, mouth, eyes, nasal passages and external auditory meati. Abrasions of the skin and catarrh of the mucous membranes must be considered as potential dangers. Unremitting attention to hygiene should begin with the birth of the child.

\section{Summary.}

1. Clinical observations from the time of birth are described in connection with twenty-one cases of meningitis in newborn infants. Details are given of the findings at eighteen autopsies. The results of bacteriological examination of specimens obtained during life and at post-mortem examination are recorded.

2. Meningitis is usually part of a generalized septicaemia but it is not always possible to determine whether infection of the meninges has been by the blood stream or as the result of direct extension from other foci.

3. The bacteriology of meningitis differs in the newborn from that found in older subjects. Neonatal meningitis is frequently the result of b. coli infection; occasionally it results from infection by organisms of comparative rarity. In the twenty-one cases described b. coli was the causal organism in approximately half that number; in one infant meningitis resulted from septicaemia due to an atypical organism of the Salmonella group.

4. Morbid conditions of the skin, subcutaneous tissues or surface mucous membranes were present in fifteen cases. Their presence, especiallv in premature infants, constitutes a definite risk of meningitis.

5. Infection of the mouth and nasal passages is associated with special risks on account of the ease with which extension may occur along the eustachian tubes and give rise to otitis media and subsequent meningitis.

6. Neonatal meningitis cannot always be diagnosed. The classical signs of meningitis are often absent. Importance is attached to prematurity and the presence of infection as predisposing factors. Signs of intracranial disturbance occurring after the first week of life should always suggest meningitis; of these ocular signs, sponginess of the fontanelle, and mental restlessness are the most common. Fever of a few days' duration usually precedes death. Convulsions are rare. The condition has to be differentiated from pneumonia in afebrile cases, and from intra-ventricular haemorrhage in the presence of signs arising from increased intracranial pressure. Lumbar puncture is essential for a final diagnosis. 
7. Neonatal meningitis illustrates the seriousness of the threat to survival in infection of the newborn. The skin and surface mucous membranes are common portals of entry for infection. The danger of infection can be greatly lessened by meticulous attention to the hygiene of the skin, mouth, eyes, nasal passages and external auditory meati. This care should commence with the birth of the infant.

Thanks must be expressed to Prof. Charles McNeil and to Prof. R. W. Johnstone for their advice and encouragement; to Dr. A. R. Macgregor for the majority of the bacteriological reports; and to Col. W. F. Harvey, Col. Glen Liston and Dr. W. D. Kermack, all of the Laboratory of the Royal College of Physicians, Edinburgh, for various investigations in connection with specimens of cerebro-spinal fluid. Dr. C. P. Beattie must also be thanked for reports in connection with the bacteriology of one case.

\section{Appendix.}

Dr. C. P. Beattie, of the University Bacteriological Department, Edinburgh, carried out investigations in connection with the organism found in case No. 211 (table 2). He reported as follows:-

The organism was a gram negative, non-motile bacillus. The nonmotility of the organism was a considerable bar to its identification as it was impossible to make use of ' $\mathbf{H}$ ' antigens. It remained non-motile in spite of frequent subcultures in broth. The sugar reactions were glucose positive, lactose negative, dulcite positive, saccharose negative, mannite positive, xylose positive, inosite negative, glycerine negative, adonite negative, archinose positive, raffinose negative, salicin negative, rhamnose positive, lead acetate agar-blackened, indol negative, Voges-Proshauer negative, gelatin-not liquefied.

The organism was tested against representative sera of the various ' $O$ ' groups with the following results:-

Organism.

Group.

Titre.

$\begin{array}{lccccccc}\text { Paratyphosus } & \text { A } & & & & & & \\ \text { Paratyphosus } & \text { B } & \ldots & \ldots & \ldots & \ldots & \text { VI } & 6,400 \\ \text { Gaertner } & \ldots & \ldots & \ldots & \ldots & \ldots & \text { I, II } & 1: 400 \\ \text { Suipestifer } & \ldots & \ldots & \ldots & \ldots & \text { III } & 1: 3200 \\ \text { Newport } & \ldots & \ldots & \ldots & \ldots & \ldots & \text { V } & 0 \\ \text { " L } & \ldots & \ldots & \ldots & \ldots & \ldots & \text { IV } & 0 \\ \end{array}$

The organism if of the Salmonella group appeared to have ' $O$ ' antigen III or VI or both.

The absorption test showed it not to be 'paratyphosus $A$ ' or $\mathbf{B}$. enteritidis Gaertner. The organisms with the same ' $O$ ' as Para. A. is Newcastle. With this the organism gave only a low titre agglutination. In view of the sugar reactions and serological test the organism may have been a non-motile variant of Dar-es-Salaam, Eastbourne or Tokyo. On the other hand, it more probably belonged to a strain not previously identified. 


\section{REFERENGES.}

1. Aries, L. J., Pilot, I., \& Shaffer, M. S., Am. J. Obst. \& Gynec., St. Louis, 1932, XXIII, 745.

2. Athenstaedt, F., Zentralbl. f. Gynäk., Leipzig, 1933, LVII, 2302.

3. Aschoff, L., Ztschr. f. Ohren, Berlin, 1897, XXXI, 2952.

4. Barron, M., Am. J. Med. Sc., Philadelph., 1918, CLVI, 358.

5. Bradford, W. L., \& Kelly, H. W., Am. J. Dis. Child., Chicago, 1933, XLVI, 543.

6. Browne, F. J., Edin. Med. J., Edin., 1921, XXVII, 153.

7. Cathala, J., \& Gabriel, P., Bull. Soc. de pédiat. de Paris, Paris, 1933, XXXI, 174.

8. Cooke, J. V., \& Bell, H. H., Am. J. Dis. Child., Chicago, 1922, XXIV, 387

9. Craig, W. S., Edin. Med. J., Edin., 1935, XLII, 599.

10. Craig, W. S., Arch. Dis. Childh., London, 1935, X, 337.

11. Cruickshank, J. N., Med. Res. Counc. Spec. Report, No. $145,1930$.

12. Fothergill, L. D., \& Sweet, L. K., J. Paed., St. Louis, 1933, II, 696.

13. Gibbens, J., Lancet, London, 1932, i, 1298.

14. Goldreich, W., Jahrb. f. kinderheilk., Berlin, 1902, LVI, 808, quoted by Barron, M.

15. Herrman, C., Arch. Pediat., New York, 1915, XXXII, 384.

16. Hinsdale, G., Am. J. Med. Sc., Philadelph, 1899, CXVIII, 280.

17. Koplik, H., Arch. Pediat., New York, 1916, XXXIII, 481.

18. Leathart, P. W., Brit. Med. J., London, 1932, ii, 693.

19. Neff, F. C., Abt's Paediatric's, London, 1924, VII, 523.

20. Ravid, J. M., Am. J. Dis. Child., Chicago, 1935, XLIX, 1282.

21. von Reuss, A., Diseases of Children, by Pfaundler, M., \& Schlossmann, A., English translation by Peterman, M. G., London, 1935, 4.

2غ. von Reuss, A., Diseases of the Newborn, London, 1920.

25. Scherer, F., Jahr. $f$.kinderheilk, Berlin, 1894, XXXIX, 1. 